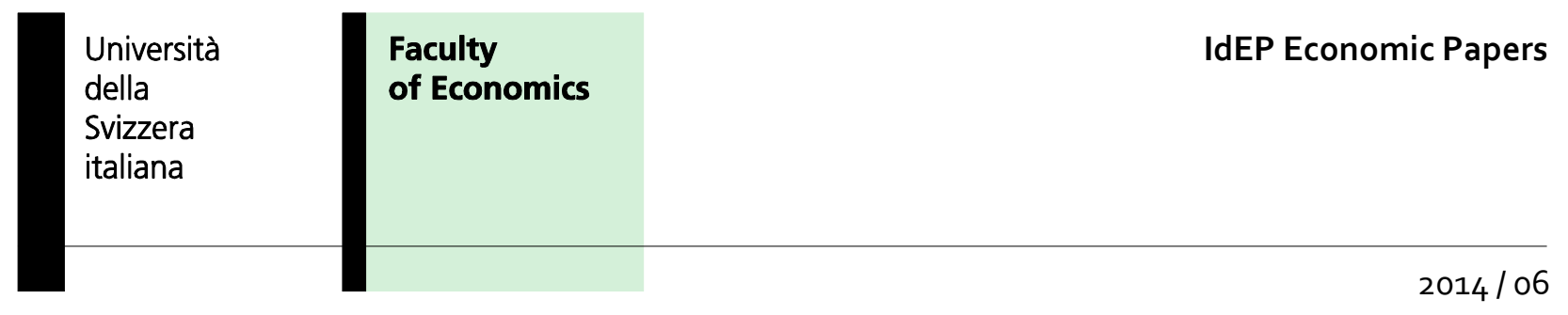

U. Pagano, M. Vatiero

Costly institutions as substitutes : novelty and limits of the Coasian approach 


\title{
Costly Institutions as Substitutes: Novelty and Limits of the Coasian Approach
}

\author{
Ugo Pagano (University of Siena) \\ and \\ Massimiliano Vatiero (Università della Svizzera italiana, vatierom@usi.ch)
}

\begin{abstract}
One of the main contributions of Ronald $\mathrm{H}$. Coase was to demonstrate how mainstream economics was based on a contradictory amalgam of costly physical inputs and free institutional resources, and to gave origin the economics of institutions: each institution is a mode of allocation and organization of economic resources that is to be investigated. In particular, none of the institutions (including the market) is a free lunch. The Coasian approach regards institutions as costly substitutes and provides a fundamental starting point for comparative institutional analysis. However, Coase neglected two issues deriving from the observation that institutions are not cost-free. First, when institutions are costly, one should not only consider their possible substitutes but also how complementary institutions affect their costs, as well as the costs of the possible institutional substitutes. Secondly, the economic analysis should also take into account that the transition from one institutional setup to another cannot occur in costless meta-institutions. The initial conditions may substantially affect the final institutional arrangements. Both the novelty of Coase's approach and its limits were grossly undervalued. The costly institutions assumption requires a view of economics as a historical discipline.
\end{abstract}

Keywords: Ronald Coase, transaction costs, institutions, institutional complementarities. 
"You will not float down, like a sickly fish, with the tide [...]
you enjoy considerable mental vigour
and are not a passive instrument in the hands of others [...]
you are more inclined to think and work for yourself»
a phrenologist to Coase, when he was 11 years old

(R.H. Coase 1992)

\section{Introduction}

The classic, or better the standard, neo-classical economic problem has been how to allocate economic resources in such a way as to maximize welfare. In the simplest economy represented by the Edgeworth box, economic agents, bartering for their goods, achieve some point on the Pareto set (i.e. the contract curve). That is, by means of individual exchanges the market takes care of the efficient allocation process - this is an expression of the First Fundamental Theorem of Welfare Economics. The conditions on which this Theorem is based are that economic resources are costly, while the institutional allocation process namely the market, which can achieve efficiency - is cost-free. Economic resources are costly because they are scarce: that is, their complete and universal consumption is not possible. On the other hand, the Theorem applies merely to a world where market clearing is free. In this respect, the standard neo-classical approach consists of a contradictory amalgam of costly physical inputs and free institutions, i.e. (good) institutions are without cost in a world in which resources are costly. The main contribution of Ronald Coase was to investigate how costly resources are allocated within likewise costly institutional arrangements.

The purpose of this article is to explore Coase's novelty and, in doing so, provide additional insights into the central theme of his contributions to economic analysis. We will argue that removing the assumption of null transaction costs entails not only that institutions (within which costly goods are substituted) are costly, but also that the Coasian substitution among different institutions has to be grounded on positive costs due to institutional transition. Moreover, the condition of costly institutions leads to a second result, one rather neglected by the Coasian approach: all costly inputs (including institutions) are characterized not only by substitution but also by complementarity relations. Both issues require a historical/evolutionary approach to the analysis of economic systems.

According to Robbins' definition of economics as the science of choices, economists study how consumers choose to purchase goods and services and how producers decide on what production factors to employ and which quantities of products to make and supply. These choices are expressed through a rate of substitution, i.e. the marginal rate of substitution on the consumption side and the marginal rate of substitution on the production side. Besides the choice among physical resources, Ronald Coase introduced 
into the economic investigation the choice among institutions (or institutional resources): "economic policy involves a choice among alternative social institutions" (Coase 1988a: 28, italics is added). This choice is based on the fact that every institution, as well as every physical resource, is costly.

Accordingly, the market is not "an automatic self-regulating system" (see Coase 1937, 1972, 1988) or locus naturalis (Irti 1994); rather, it has costs of functioning or costs for performing a certain transaction. These have come to be known in the economic literature as transaction costs. Such costs are

necessary to discover who it is that one wishes to deal with, to inform people that one wishes to deal and on what terms, to conduct negotiations leading up to a bargain, to draw up the contract, to undertake the inspection needed to make sure that the terms of the contract are being observed, and so on (Coase 1960: 15).

And again, they are "costs of discovering what the relevant prices are; [...] costs of negotiating and completing a separate contract for each market transaction" (Coase 1972: 63).

The concept of transaction costs was introduced in Coase's article of 1937 (in terms of "the cost of using the price mechanism", "the cost of carrying out a transaction by means of an exchange on the open market"), and it was developed in his article of 1960 with the phrase "the costs of market transactions". However, in the literature these two articles, for which Coase was awarded the Nobel Prize by the Royal Swedish Academy, have rarely been linked together in a single powerful theoretical framework, and they have sometimes even been seen as contradictory - a socialist vs. a liberal Coase. ${ }^{1}$ Yet Coase's two main articles represent two pieces of the same analysis (see Calabresi 1991, Pagano 2012) aimed at developing the concept of transaction costs in order "to understand the working of the economic system, to analyse many of its problems in a useful way, or to have a basis for determining policy" (Coase 1988a: 6). Because of the existence of transaction costs, economic analysis has to rely on careful study of the actual functioning of different institutions and on meticulous comparative institutional analysis. Unfortunately, this point of view, in the words of Coase (1988a: 1), "has not in general commanded assent", nor has it "for most part, been understood".

The aim of this work is to stress the novelty of the Coasian approach and, at the same time, to analyse its two main limitations. First, whilst in the Coasian approach institutions are investigated as alternative/substitute instruments for achieving efficiency, we will argue that if all institutions are costly, then a significant degree of complementarity may arise among them. Second, the existence of institutional complementarity involves the evolution (not necessarily converging) of economic systems, and it is at odds with approaches (including Coase's), in which the market is also contradictorily represented as an ahistorical meta-institution.

The article is structured as follows. In the next section, we summarize the novelty of Coase's thought in the field of institutional economics. Section 3 deals with the meaning of institutional complementarity and how it can improve and extend the Coasian approach. Section 4 shows the essential role of historical analysis in the understanding the evolution and the diversity of actual institutions. Section 5 summarizes our main points, arguing that only a historical approach can fully develop the insights of the Coasian approach and offer a solution to its contradictions.

\footnotetext{
${ }^{1}$ Guido Calabresi (1991: 1211) noted:

Some fifty-five years ago, in a seminal article called The Nature of the Firm, a young socialist named Ronald Coase sought to explain the existence of firms, of organizations within which markets were replaced by hierarchy and command. Twenty-five years later, in The Problem of Social Cost, Ronald Coase, by then a middle-aged libertarian, indicated how markets could replace hierarchy and command structures to the perceived benefit of those who organized them.
} 


\section{Costly institutions: the consistency of the Coasian contributions}

The substance and the purpose of institutions rest on reducing costs of transaction: "Markets are institutions that exist to facilitate exchange, that is, they exist in order to reduce the cost of carrying out exchange transactions" (Coase 1988a: 7). Subsequently, if the cost of performing the transactions in the market is higher than in firms, then firms "substitute" markets in that task.

Within a firm [...] market transactions are eliminated, and in place of the complicated market structure with exchange transactions is substituted the entrepreneur-co-ordinator, who directs production. It is clear that these [i.e. market and firm] are alternative methods of co-ordinating production (Coase 1937: 388 , italics is added).

And again, Coase maintains that "the operation of a market costs something and that, by forming an organization and allowing some authority (an "entrepreneur") to direct the resources, certain marketing costs are saved" (Coase 1937: 392).

Thus, the main argument delivered by Coase in "The Nature of the Firm" is that firms exist because there are costs of using the price mechanism and these costs can be reduced by the use of an administrative structure. The firm's ability to substitute administrative fiat for bargaining may resolve concerns linked to dealing with transactions at a lower cost than in the market. In this respect, "The most important adaptation to the existence of transaction costs is the emergence of the firm" (Coase 1988a: 7). On the other hand, the administrative costs of firm organization may be very high, perhaps exceeding the costs of market organization. For this reason,

a firm will tend to expand until the costs of organizing an extra transaction within the firm become equal to the cost of carrying out the same transaction by means of an exchange on the open market or the costs of organizing in another firm (Coase 1937: 395).

Besides market and firm, a further institutional alternative for handling transactions and reducing transaction costs is governmental regulation. Coase (1960) maintained that the government could act as a "super-firm" through its ability to allocate resources by administrative fiat. In particular, the government may impose regulations through, for instance, administrative agencies - in its activity, the government, unlike the firm, also has the monopoly of coercion (by the police) at its disposal. However, nor is the government machine costless. There are governmental failures due, for instance, to incomplete information on benefits and costs, as well as producer or consumer preferences. Then, when the costs of governmental regulation are higher than market costs, the transaction should come back to the market - this was the main argument in regard to broadcasting frequencies put forward by Coase in his article "The Federal Communication Commission" - or carried out within the firm.

Hence, whilst in the case of markets the movement (trans-action) of a resource from an agent $\mathrm{Y}$ to an agent $\mathrm{X}$ is carried out in a completely decentralized way by the price-mechanism, in the firm and in the State this movement or transaction is performed mainly by administrative decisions and hierarchical structures based on authority. Hence, Coase $(1937,1960)$ affirms, there are multiple (not obvious) options for dealing with transactions. $^{2}$ And in regard to the Coasian approach, the economic investigation should explicate the functioning of these different modes of allocation and organization.

Moreover, in 1960 Ronald Coase showed that the essential ingredient of efficient markets - as stated in the First Fundamental Theorem of Welfare Economics - is the (definition and enforcement of) property rights: in the market, the trade of resources relies on alienable rights (that is, property rights) and consists

${ }^{2}$ However, one of the aforementioned institutional solutions should be chosen only if the net benefits which would result from the institutional rearrangement of activities is positive; otherwise, a last option is inertia, "to do nothing about the problem at all" (Coase 1960: 18). 
of an exchange of rights on uses deriving from these resources. Like the Old-Institutionalists ${ }^{3}$ about ninety years ago (e.g. Commons 1924), Coase affirmed that markets require "the establishment of legal rules governing the rights and duties of those carrying out transactions in these facilities" (Coase 1988: 10) and the enforcement of these rules in order to secure the agreement of the parties to the exchange. This is the "legal Nirvana" which presupposes clear and enforced property rights, and it leads to the "economic Nirvana" in which the market wholly clears (Nicita and Pagano 2008). Furthermore, Coase (1960) demonstrates that there is no (analytical) difference between rights on piece of land and those allowing, for instance, the emission of smoke. If rights are well defined, also the market transaction of rights to smoke could lead to Pareto efficiency. Hence, more precisely defined and easily tradable property rights may improve market exchanges and lead to a Pareto efficient allocation of resources, for every kind of economic resource.

In the Coasian approach, an externality (i.e. the effect of one agent's action on the welfare of another leading to the divergence between the private and social product of such an action) represents the absence of a market instead of the presence of a market failure. Externality has a reciprocal nature and consists essentially of interferences between rival uses of the resource, e.g. the Rancher's use of the land to herd cattle $v s$. the Farmer's use of it to grow crops. Externality problems are ultimately property rights problems and may be solved by defining property rights clearly and by facilitating the trade of resources. Each property right should specify the relevant attributes (including the enforcement) of each use of the resource and the contingencies that characterize such uses. Accordingly, externality problems do not constitute a prima facie case for public intervention (taxation or regulation) as affirmed by the Pigovian tradition $-\mathrm{a}$ policy insight that induced Coase to write, quite accidentally, "The Problem of Social Cost".

Assuming null transaction costs, once property rights have been defined, the parties will exchange them, maximizing the joint value of activities. This first thesis reappraises the statement of the First Fundamental Theorem of Welfare Economics, even if it underlines the fact that the Theorem is based and depends on well-defined property rights. Moreover, Coase demonstrates a further thesis: "the ultimate result (which maximizes the value of production) is independent of the legal position if the pricing system is assumed to work without cost" (Coase 1960: 104). These two theses, the so-called efficiency and invariance thesis respectively, compose the Coase theorem. ${ }^{5}$

In the absence of transaction costs, it does not matter what the law is, since people can always negotiate without cost to acquire, subdivide, and combine rights whenever this would increase the value of production. (Coase 1988a: 14).

However, the world of zero transaction costs, to which the Coase theorem applies, and which Coase (1988: 15) considers "the world of modern economic analysis", is not the actual world. Above all, in such a world

\footnotetext{
${ }^{3}$ For a critical analysis of legal relations in the economic system along with the American Old-Institutional perspective, see Fiorito and Vatiero (2011) and Vatiero (2013) on this Journal.

${ }^{4}$ Indeed, it is probable that "The Problem of Social Cost," one of the most extensively cited articles in the whole of the modern economic literature, would never have been written if about twenty Chicagoan economists, such as Director, Friedman and Stigler, had not thought that Coase had made (what Stigler later referred to as) an "obvious mistake" and even "heresy" in his article of 1959 on "The Federal Communications Commission" (see Coase 1988, and also Medema 2009).

${ }^{5}$ As well known, Ronald Coase himself declined to use the label "Coase theorem". The reformulation of Coase's argument in the form of a theorem is attributed to George Stigler (Coase 1988a, 1988b) as follows: under perfect competition, private and social costs will be equal. Other formulations, before and shortly after Stigler's are by Buchanan and Tullock (1962), Demsetz (1967) and Calabresi (1968): for Buchanan and Tullock (1962: 47-48), "if the costs of organizing decisions should be zero, all externalities would be eliminated by voluntary private behaviour regardless of the initial structure of property rights"; Demsetz (1967: 349) asserts that "in a world of zero transaction costs [...] the output mix that results when the exchange of property rights is allowed is efficient and the mix is independent of who is assigned ownership"; finally, for Calabresi (1968: 68), "if one assumes rationality, no transaction costs, and no legal impediments to bargaining, all misallocations of resources would be fully cured in the market by bargains". Subsequently, the Coase theorem has been stated in numerous further ways (see Medema and Zerbe 1999), and also by Coase himself: "under null transaction costs, private and social costs will be equal” (Coase 1988b: 158).
} 
institutions have no consistency, i.e. there are "firms without organization, and even exchange without markets" (Coase 1988a: 3); given that market, firms, and each institutional arrangement exist (at least in part) to reduce the transaction costs in the economic system, if we assume that these costs do not exist, then economic investigation does not require analysis of the actual market, actual firms and each actual institutional arrangement. On the contrary, the study of transaction costs requires study of the functioning of institutions.

In 1981, Ronald Coase stated that

while consideration of what would happen in a world of zero transaction costs can give us valuable insights, these insights are, in my view, without value except as steps on the way to the analysis of the real world of positive transaction costs. We do not do well to devote ourselves to a detailed study of the world of zero transaction costs, like augurs divining the future by the minute inspection of the entrails of a goose (Coase 1981: 187)

Instead of inspecting a goose and imagining worlds with null transaction costs, Coase concluded his article "The Problem of Social Cost" by stating:

We have the costs involved in operating the various social arrangements $[\ldots]$ as well as the costs involved in moving to a new system. In devising and choosing among social arrangements we should have regard for the total effect. This, above all, is the change in approach which I am advocating (Coase 1960: 44)

Accordingly, when transaction costs are involved, economic agents generate economic institutions in order to minimize transaction costs and

[t] he way in which industry is organized is thus dependent on the relation between the costs of carrying out transactions on the market and the costs of organizing the same operations within the firm [or other institutional arrangements] which can perform this task at the lowest cost (Coase 1972: 64)

Paraphrasing Milton Friedman's popular slogan There is no such thing as a free lunch, meaning that there is no socially relevant human need whose satisfaction is free, Coase shows that the issue of institutional substitution arises when none of the institutions is a "free lunch". In this sense, Coase provided a fundamental starting point for the comparative analysis of institutions.

However, the Coasian approach does not deal with two important issues stemming from the removal of free-lunch institutions. Costly lunches involve not only the substitution of the items on the menu but also their complementarities. One item on the menu may be (or not be) substituted by another if the complementary ingredients are present (or lacking). Moreover, if one ignores the historical set-up and its interlocking complementarities, one is forced to assume the existence of costless meta-institutions where institutional substitution takes place. Some knowledge of history is required to understand the complementary institutional factors framing a particular institutional substitution choice. As in the title of Hodgson's (2001) book, extending the analysis to costly institutions entails that economics cannot forget history.

\section{Beyond Coase: institutional complementarities.}

In his pivotal book Markets and Hierarchies, Oliver Williamson succinctly summarized the Transaction Cost Economics generated by Coase's argument as follows:

(1) Markets and firms are alternative instruments for competing a related set of transactions; (2) where a set of transactions ought to be executed across markets or within a firm depends on the relatively efficiency of each 
mode" (Williamson 1975: 8, italics is added).

These two statements recapitulate the novelty of the Coasian view: namely that economic analysis should include the study of substitution among costly institutions; but they also indicate its limitations: the exclusion of institutional complementarities and history from economic analysis. Indeed, the fact that institutions are costly implies not only that institutional arrangements are substitutes intended to reduce transaction costs, but also that a certain degree of complementarity (or bundling) among institutions may be needed. ${ }^{6}$

When the "performance" of one institution is conditioned by and benefits from the presence of another institutions and vice-versa, we speak of institutional complementarity ${ }^{7}$; when, instead, the presence of one institution undermines the functioning of another, we speak of institutional crowding out. ${ }^{8}$ For instance, the more a market of production factors clears, the more efficiently a firm produces; the more efficiently a firm produces, the more tax-revenue the State may collect and use to provide better courts for the protection of rights; and the more property rights are protected, the more the market clears; and so on (see Vatiero 2009, ch. 4). Put briefly, private ownership, competitive markets and the rule of law often implement highly efficient solutions to allocation problems, but only if all three components are present (see Bowles 2004: 12).

The notion of institutional complementarity (Milgrom and Roberts 1990, Pagano and Rowthorn 1994, Aoki 2001) relies on the idea that, in a given institutional framework, economic agents operate in different institutional domains. As a consequence, choices in one domain act as exogenous parameters in other domains and constitute the institutional environment in which institutional choices are made. According to Aoki (2001), institutional complementarities are situations of synchronic interdependence across distinct institutional domains. In this setting "one type of institution rather than another becomes viable in one domain, when a fitting institution is present in another domain and vice-versa" (Aoki 2001: 225).

The term "fitting" used by Aoki invokes an evolutionary approach to institutional contexts. Accordingly, a growing body of literature shows that the evolution of economic systems may share some of the complicated intellectual challenges that characterize the Darwinian evolution of natural species in biology ${ }^{9}$ (Hodgson 1993). As long as institutional complementarities are deep and strong, they can affect, or conceivably determine, the best-fitting institutional arrangements, and that system will differ depending on which local complement dominates.

Analytically, suppose two institutional domains, $\sigma$ and $\varphi$, and with $A$ and $B$ as two "species" of each domain. Assuming a payoff function $u$, let us suppose the following conditions:

\footnotetext{
${ }^{6}$ In some passages, also Coase seems to suggest the idea of complementarity/bundlimg among different institutional tools. For instance he argues that "for anything approaching perfect competition to exists, an intricate system of rules and regulations would be normally be needed [...] regulation may play in widening the market" (Coase 1988a: 9), and that "the interrelationships which govern the mix of market and hierarchy [...] are extremely complex" (Coase 1992: 718). These arguments imply that if the market is to achieve efficiency, it needs also complementary institutions such as hierarchical structures and governmental regulations.

7 Complementarity is a recurrent and somewhat contentious topic of study for economic analysis. For instance, while Paul Samuelson in 1947 affirmed that "in my opinion, the problem of complementarity has received more attention than is merited by its intrinsic importance" (Samuelson 1947: 183), he later corrected himself in 1974, by asserting that "the time is ripe for a fresh, modern look at the concept of complementarity" (Samuelson 1974: 1255). On the notion of complementarity, see also Vatiero (2009).

8 See Bowles (2004). One of the most frequently quoted examples of institutional crowding out is offered by Gneezy and Rustichini (2000): the use of a market mechanism (the fine as a price) seems to have undermined parents' sense of obligation to avoid inconveniencing teachers by taking their children on time to school.

${ }_{9}^{9}$ Coase believes that a more accurate depiction of human behavior can be found in biology, where human nature is seen as an outcome of a long-term evolutionary process in which genetic influences play an important role (Coase 1978: 244-245). However, Coase does nothing to develop these ideas.
} 


$$
\begin{aligned}
& u\left(\sigma^{A}, \varphi^{A}\right)-u\left(\sigma^{B}, \varphi^{A}\right) \geq u\left(\sigma^{A}, \varphi^{B}\right)-u\left(\sigma^{B}, \varphi^{B}\right) \\
& u\left(\varphi^{A}, \sigma^{A}\right)-u\left(\varphi^{B}, \sigma^{A}\right) \geq u\left(\varphi^{A}, \sigma^{B}\right)-u\left(\varphi^{B}, \sigma^{B}\right)
\end{aligned}
$$

Conditions [1] and [2] illustrate the situation in which the difference between the payoff from species $A(B)$ and that from species $B(A)$ increases if the institutional environment is of type $A(B)$ rather than $B(A)$. Hence, the presence of species $A(B)$ in one domain benefits and is benefited by the presence of the same species in the other domain. This expresses the idea of complementarity between two different domains. It can be proved that the two strategy profiles $\left(\sigma^{A}, \varphi^{A}\right)$ and $\left(\sigma^{B}, \varphi^{B}\right)$ may be Nash equilibrium profiles (Aoki 2001, see also Milgrom and Roberts 1990). When these two equilibria exist, $\sigma^{A}$ and $\varphi^{A}$ as well as $\sigma^{B}$ and $\varphi^{B}$ are called 'institutional complements'. Note that these two equilibria may be ranked in terms of efficiency: for instance, equilibrium $\left(\sigma^{A}, \varphi^{A}\right)$ may be Pareto superior to $\left(\sigma^{B}, \varphi^{B}\right)$. Hence, institutional complementarities may engender, not a tendency towards systemic efficiency, but the emergence of different and (in)efficient economic equilibria.

Moreover, the emergence of multiple equilibria, namely $\left(\sigma^{A}, \varphi^{A}\right)$ and $\left(\sigma^{B}, \varphi^{B}\right)$, means that the convergence towards a certain Pareto-efficient equilibrium will be more complicated in both theory and practice than a simple smooth and expectable change. Indeed, institutional interdependences lead to patterns that Gunnar Myrdal and institutionalists such as William K. Kapp termed "circular and cumulative causation" and are now called "path-dependency". Because of institutional complementarities, small changes may have durable consequences on "hybrid" situations, e.g. disequilibrium among institutional complements such as $\left(\sigma^{A}, \varphi^{B}\right)$ and $\left(\sigma^{B}, \varphi^{A}\right)$. They may set off a circular and cumulative causation process leading rapidly to an equilibrium. On the other hand, big changes may not produce institutional or economic readjustments because of the costs of switching from one equilibrium to another; in this case the initial condition may have persistent "lock-in" effects ${ }^{10}$ - this is one of the (unfortunately implicit and untested) conditions of the so-called legal origins theory (e.g. La Porta et al. 1999).

Institutional complementarity entails that economics, similarly to evolutionary biology, is a historical discipline. When institutions are costly, one should consider not only their possible substitutes but also how complementary institutions affect their costs and the costs of the possible institutional substitutes. Whereas in the Coasian approach optimal institutional substitution implies the existence and the convergence to a single optimal equilibrium, institutional complementarities entail that multiple (and possibly inefficient or non-comparable) equilibria can well exist. ${ }^{11}$

\section{The market as a meta-institution: difficulties of the Coasian approach.}

Also in this section a quotation from Oliver Williamson provides a useful starting point. In his book Markets and Hierarchies, Williamson writes: "I assume, for expositional convenience, that in the beginning

\footnotetext{
${ }_{10}$ Biologists use the term punctuated equilibrium to refer to this alternating pattern of rapid stasis change (Eldredge and Gould 1972).

11 Multiple equilibria stemming from institutional complementarities can offer explanations for institutional arrangements in several contexts. For instance, they can aid understanding of why some markets work differently than others (e.g. Aoki 2001, Bowles 1998, Bowles and Gintis 1993), why some firms are organized differently from others (e.g. Aoki 2001, Pagano 2011, Pagano and Rowthorn 1994), why some societies are structured differently from others (e.g. Heinrich et al. 2001), and above all why different varieties of capitalism emerge and persist (Amable 2003, Belloc and Pagano 2013, Hall and Gingerich 2009, Hall and Soskice 2001, Roe 2003).
} 
there was the market"' (Williamson 1975: 20). As this statement shows, a recurrent condition of transaction costs economics is that the market, like a product of Immaculate Conception (Dugger 1992: 89), is assumed to pre-exist other institutional substitutes (see also Hodgson 1988: 177-182). This assumption that in the beginning there was the market limits the analysis of the consequences of costly institutions and involves the puzzling idea that costless meta-markets are available to select other institutions, including ordinary markets. (Meta)-markets assume the contradictory status of being both among the costly institutions to be selected and the only costless institutions by which all the institutions are selected. The assumption that in the beginning there was the market means losing large part of the analysis stemming from Coase's insight of costly markets and, in general, of non-free-lunch institutions.

These limitations are particularly evident in the case of institutional rearrangements deriving from technological shocks. In 1937 Coase maintained that technological innovation can change the institutional context; "[c]hanges like the telephone and the telegraph, which tend to reduce the cost of organising spatially, will tend to increase the size of the firm" (Coase 1937: 397). The idea is that "[i]nventions which tend to bring factors of production nearer together, by lessening spatial distribution", that is, by exploiting economies of scale, "tend to increase the size of the firm" (Coase 1937: 397). Furthermore, in a footnote he also underlined that:

It should be noted that most inventions will change both the cost of organising and the costs of using the price system. In such cases, whether the invention tends to make firms large or smaller will depend on the relative effect of these two sets of costs. For instance, if the telephone reduces the costs of using the price mechanism more than it reduces the costs of organising, then it will have the effect of reducing the size of the firm (Coase 1937: 397, ft. 3).

In other words, the optimal institutional bundle, consisting of features from different institutions, is recalculated and implemented each time that the technological data change. ${ }^{12}$ However, such an institutional rearrangement seems to be cost-free, as if some costless meta-markets take care of the transition from markets and firms (and vice-versa). The transition from a market price-mechanism to a hierarchy such as the firm, due to the development of new technologies, occurs without significant costs. Thus, Coasian markets seem to have a double role in the reaction to technological innovations,: on the one hand, they represent one of the possible costly institutional substitutes; on the other, they serve as a cost-free meta-institution within which the other institutions are efficiently substituted. The functioning costs of markets limit the size of markets and explain the emergence of firms. At the same time, (meta-)markets justify the emergence of an efficient mix of markets and firms. Their functioning costs do not affect the achievement of an efficient institutional bundle, and they do not constrain the transition, required by technological change, from one organization to the other.

If we take serious account of Coase's intuition that neither markets nor firms can be first best solutions (in the sense that they are both constrained by their own costs of functioning), then the transition from market-type to firm-type organization (and vice-versa) must also be grounded on the analysis of transaction costs. Costly institutions have to be substituted in a costly institutional context. The existence of transaction costs implies the existence of transition costs: in a world of positive transaction costs, transition, or institutional switching, costs must also be positive. With significant transition costs, the institutional bundle may not simply tend to optimally correspond to the level of technological development, but must be heavily influenced by the pre-existing institutional structure of the economy. In other words, high costs of transition may inhibit or reduce potential (efficient) institutional rearrangements even in the presence of significant technological shocks. For this reason, the assumption that in the beginning there was the market neglects the fact that the substitution of institutions may not occur because of transition

${ }^{12}$ However, the reverse causation may also hold: the institutional bundle may affect the choice of technology (see Braverman 1974, Pagano and Rowthorn 1994). 
costs. It fails to understand that each transition occurs in a pre-existing institutional context, which is often characterized by numerous interlocking complementarities.

If one wants to avoid the "Nirvana fallacy" of a zero transaction world, one has to specify the relations of the initial institutional set-up and the costs of the potential institutional changes. In other words, one must move towards a history-dependent economics. A consistent Coasian approach must necessarily lead to some form of "evolutionary" economics where the initial institutional features are necessarily relevant to the explanation and the prediction of the final outcomes. Unfortunately, Coase did not consider these logical consequences of his analysis and failed to consider economics as a historical discipline.

A historical perspective should start from the fact that costly institutions (including the market), where costly resources are allocated, must evolve in a costly manner. Institutional substitution is not determined in a meta-market Nirvana but it occurs within a pre-existing institutional bundle constraining the set and the costs of institutional substitution. New technologies such as the telephone (analysed by Coase in his 1937 article) cannot be the only factors determining the future institutional bundle. Each transition (as well as each stasis of an economic system) is always influenced also by the past mix of institutions and by their interlocking complementarities. As a result, the development of markets and of other institutions is a historical outcome influenced by other complementary domains such as the legal context and politics. A further consequence is that "institutions are not necessarily or even usually created to be socially efficient, rather they, or at least the formal rules, are created to serve the interests of those with the bargaining power to devise new rules" (North 1990:16) ${ }^{13}$.

Linking institutions and institutional change only to economic performance and technological changes sets serious limitations on economic analysis. One should analyse institutions with respect to the establishment and evolution of social and political compromises. Institutional change is often the outcome of strategies aimed at improving the situation of some or all components of the dominant elite. Mancur Olson's early contribution The Rise and the Decline of Nations and Daron Acemoglu's recent book (with J.A. Robinson) Why Nations Fail consider numerous historical examples of how the logic of groups' collective behavior may favour or damage the growth of nations by changing the institutions of society. The main result of this stream of literature is that historical specificity matters because "past institutional choices open up some paths and foreclose others for future institutional development" (Ostrom, 1990: 202).

\section{Conclusion}

Using "the beautiful simple prose of the accomplished English essayist" (Posner 1993: 205) ${ }^{14}$, Coase demonstrated how mainstream economics was based on a contradictory amalgam of costly physical inputs and free institutional resources. Ronald Coase removed the assumption of free institutions and extended the logic of "efficient" substitution to costly economic institutions.

According to Robbins's classical definition, economics is the science of human choice, i.e. substitution among amounts of consumer goods and production factors. In many respects, Coase's contribution was a logical extension of this choices/substitution approach to institutional contexts: if all institutions (including the market) are costly, we have a bigher order substitution problem regarding the institutions within which

\footnotetext{
13 Similarly, Amable (2003) defines institutions as political economy equilibria in the sense that they correspond to a compromise between conflicting social actors. Institutions derive from past and present struggles between factions with diverging interests.

14 According to Oliver Williamson (1989: 229), Coase's reluctance to formalize his argumentation slowed his influence, in particular in the case of the theory (on the nature) of the firm.
} 
physical resources are substituted. Also institutions are costly alternative modes of allocation of costly resources.

In doing so, on the one hand, while advocating a comparative analysis of institutions, Coase considered them only as substitutes and ignored their complementarities. On the other hand, Coase was faced with a related problem of logical infinite regress: also the costly institutions have to be substituted in a costly institutional context.

Coase truncated, or better ignored, these problems by implicitly assuming the existence of costless metamarkets - an assumption that, unfortunately, has become the explicit assumption of much of the subsequent transaction cost analysis and is well captured by the already cited statement that "in the beginning there was the market" (Williamson 1975: 20). In this article, we have argued that there is only one way out of the sterile logical regress involving the Nirvana fallacy of (meta...)-meta-institutions: accepting that economics is a historical science and that each institutional substitution has be examined within a certain historical context characterized by numerous institutional complementarities.

\section{References}

Acemoglu D. and J. Robinson (2012), Why Nations Fail. The Origins of Power, Prosperity and Poverty. Crown Publisher

Acemoglu D. and J. Robinson (2013), "Economics versus Policy: Pitfalls of Economic Advice", Journal of Economic Perspectives, 27 (2): 173-192.

Aoki M. (2001), Toward a Comparative Institutional Analysis, MIT Press, Cambridge.

Amable B. (2003), The Diversity of Modern Capitalisms, Oxford University Press, Oxford

Belloc, M. and U. Pagano (2013), 'Politics-business co-evolution paths: Workers' organization and capitalist concentration', International Review of Law and Economics, 33: 23-36

Bowles S. (1998), "Endogenous Preferences: The Cultural Consequences of Markets and other Economic Institutions." Journal of Economic Literature, 36(1): 75-111.

Bowles S. (2004) Microeconomics. Behaviour, Institutions and Evolution. Princeton University Press. Princeton.

Bowles S. and H. Gintis (1993), "The Revenge of Homo Economicus: Contested Exchange and the Revival of Political Economy”, Journal of Economic Perspectives, 7(1): 83-102.

Braverman H. (1974), Labour and Monopoly Capital: The Degradation of Work in the Twentieth Century, Monthly Review Press, New York.

Calabresi G. (1991), “The Pointlessness of Pareto: Carrying Coase Further.” The Yale Law Journal, 100(5): 1211-1237.

Coase R.H. (1937), “The Nature of the Firm”. Economica, 4 (16): 386-405.

Coase R.H. (1959), “The Federal Communications Commission”. Journal of Law and Economics, 2 (1): 1-40.

Coase R.H. (1960) “The Problem of Social Cost”. Journal of Law and Economics, 3 (October): 1-44.

Coase R.H. 1972. "Industrial organization: a Proposal for Research”, in Fuchs V.R. (ed.) Policy Issues and 
Research Opportunities in Industrial Organization. National Bureau of Economic Research, New York.

Coase R.H. (1978), "Economics and Biology: A Comment”. American Economic Review 68: 244-245.

Coase R.H. 1981. "The Coase Theorem and Empty Core: a Comment. Journal of Law and Economics, 24 (1).

Coase R.H. 1988a. "The Firm, the Market and the Law." In R.H. Coase (ed.), The Firm, the Market and the Law, University of Chicago Press: Chicago, pp. 1-31.

Coase R.H. 1988b. "Notes on the Problem of Social Cost", In R.H. Coase (ed.),The Firm, the Market and the Law. University of Chicago Press: Chicago, pp. 157-185.

Coase R.H. 1992. Autobiography, in Frängsmyr T. (ed.) Les Prix Nobel. The Nobel Prizes 1991. Nobel Foundation: Stockholm.

Commons J.R. (1924), Legal Foundations of Capitalism. Augustus M. Kelley Publishers, Clifton.

Dugger W. (1992), An evolutionary theory of the state and the market, in Dugger W., Waller W. (eds.) The Stratified State, Radical Institutionalist Theories of Participation and Duality. M.E. Sharp: London.

Eldredge N. and S.J. Gould (1972), "Punctuated Equilibria: an Alternative to Phyletic Gradualism". In T.J.M. Schopf T. J. M. (ed.). Models in Paleobiology, S. Francisco: Freeman Cooper \& Co, pp. 82-115.

Fiorito L. and M. Vatiero (2011), "Beyond Legal Relations. Wesley Newcomb Hohfeld's Influence on American Institutionalism", Journal of Economic Issues, 45(1): 199-222.

Gneezy A. and A. Rustichini (2000), “A Fine is a Price”, Journal of Legal Studies, 29(1): 1-17.

Hall, P.A., and D.W. Gingerich (2009). "Varieties of capitalism and institutional complementarities in the political economy”. British Journal of Political Science, 39(3): 449-482.

Hall P.A. and D. Soskice (eds) (2001) Varieties of Capitalism: The Institutional Foundations of Comparative Advantage, Oxford University Press, Oxford.

Heinrich J., S. Bowles, R. Boyd, C.F. Camerer, E. Fehr, H. Gintis, R. McElreath (2001), "In Search of Homo Economicus: Behavioral Experiments in 15 Small-Scale Societies", American Economic Review, 91(2): 7378.

Hodgson G.M. (1988), Economics and Institutions: A Manifesto for a Modern Institutional Economics. Polity Press: Cambridge (UK).

Hodgson G. M. (2001) How Economics forgot history. Routledge, London and New York.

Irti N. (1994), L'ordine Giuridico del Mercato. Bari: Laterza.

La Porta, R., F. Lopez-de-Silanes, and A. Shleifer (1999), "Corporate Ownership around the World", Journal of Finance, 54: 471-517.

Medema G.S. (2009), The Hesitant Hand. Princeton: Princeton University Press.

Medema G.S. and R.O. jr Zerbe (1999), “The Coase Theorem”. In B. Bouckaert and G. De Geest (eds.), The Encyclopedia of Law and Economics, Edwar Elgar Publishing.

Milgrom, P. and J. Roberts (1990), "Rationability, Learning and Equilibrium in Games with Strategic Complementarities", Econometrica, 58: 1255-1277.

Nicita A. and U. Pagano (2008), "Law and Economics in Retrospect". In New Institutional Economics. A Guidebook, E. Brosseau and J-M. Glachant (eds.), Cambridge: Cambridge University Press, pp. 409-425.

North, D.C. (1990), Institutions, Institutional Change and Economic Performance, Cambridge: Cambridge University Press. 
Olson M. (1982), The Rise and the Decline of Nations. Yale University Press.

Ostrom E. (1990), Governing the Commons: The Evolution of Institutions for Collective Action, New York: Cambridge University Press.

Pagano U. (2011), "Interlocking Complementarities and Institutional Change", Journal of Institutional Economics, 7(3): 373-392.

Pagano U. (2012), "No institution is a free lunch: a reconstruction of Ronald Coase", International Review of Economics, 59 (2): 189-200.

Pagano U. and R. Rowthorn (1994), "Ownership, Technology and Institutional Stability”. Structural Change and Economic Dynamics, 5(2): 221-243.

Posner R.A. (1993), "Ronald Coase and Methodology”, Journal of Economic Perspectives, 7: 195-210.

Roe, M.J. (2003) Political Determinants of Corporate Governance. Political Context, Corporate Impact, Oxford: Oxford University Press.

Samuelson P.A. (1947), "Foundations of Economic Analysis", in Harvard Economic Studies, vol. 80, Cambridge: Harvard University Press.

Samuelson P.A. (1974), "Complementarity: An Essay on the $40^{\text {th }}$ Anniversary of the Hicks-Allen Revolution in Demand Theory", Journal of Economic Literature, 12(4): 1255-1289.

Vatiero M. (2009), Understanding Power. A 'Law and Economics' Approach. Saarbrucken: VDM-Verlag.

Vatiero M. (2013), "Positional Goods and Robert Lee Hale's Legal Economics", Journal of Institutional Economics, 9(3): 351-362.

Williamson O.E. (1975), Markets and Hierarchies: Analysis and Anti-trust Implications. A Study in the Economics of Internal Organization. New York: Free Press.

Williamson O.E. (1989), "Review of 'The Firm, the Market, and the Law' by R.H. Coase", California Law Review 77: 223-231. 


\section{IdEP Economic Papers}

The series IdEP Economic Papers, ideally continues the work of the "Quaderni della Facoltà" the publication of which began in 1998 and ended in 2013.

For a complete list of the Quaderni see: http://econpapers.repec.org/paper/lugwpaper/

IdEP Economic Papers also gathers the legacy of the CEPRA Working Papers, published from 2012 to 2013.

The full list at: http://econpapers.repec.org/paper/lugwcepra/

\section{4:}

No. 01

F. Mazzonna, F. Peracchi, Unhealthy retirement? Evidence of occupation heterogeneity

No. 02

L. Di Giorgio, M. Filippini, G. Masiero, The relationship between costs and quality in nonprofit nursing homes

No. 03

F.C. Billari, V. Galasso, Fertility decisions and pension reforms : evidence from natural experiments in Italy

No. 04

M. Jametti, M. Joanis, Elections and de facto expenditure decentralization in Canada

No. 05

M. Jametti, Weathering the global financial crisis : is direct democracy of any help?

No. 06

U. Pagano, M. Vatiero, Costly institutions as substitutes: novelty and limits of the Coasian approach 